\title{
ABD Müdahalesi Sonrasında Afganistan'da İdarenin Yerel Örgütlenmesi: Türkiye Örnekleminde Bir Değerlendirme
}

Local Organization of Administration in Afghanistan After US Intervention: An Evaluation on the Sample of Turkey

Tahera YAREE

Y.L. Öğrencisi, Sakarya Üniversitesi, SBE,

Siyaset Bilimi ve Kamu Yönetimi A.B.D.,

tahera.yaree@gmail.com

https://orcid.org/0000-0002-0085-2217
Makale Başvuru Tarihi / Received: 26.04.2019

Makale Kabul Tarihi / Accepted: 17.05.2019

Makale Türü / Article Type: Araştırma Makalesi

Anahtar

ÖZET

Kelimeler:

Afganistan,

Kamu Yönetimi,

Bu çalışma Afganistan'daki yerel yönetimlerin yapısını analiz etmeyi amaçlamaktadır. Afganistan'da ABD müdahalesi sonrasında devlet yeniden örgütlenmiştir. Bu durum yerel yönetim kuruluşlarına da yansımıştır. Afganistan'da yerel yönetim kuruluşları olarak il, ilçe, belediye ve köyler bulunmaktadır. Ayrıca merkezi

Yerel Yönetimler, düzeyde Bağımsı Yerel Yönetim Müdürlüğü de yerel yönetimler alanında çalışmaktadır. Afganistan yerel

Il Yönetimi, yönetimleri demokrasi ve kalkınma hedefleri doğrultusunda yapılandırılmaya çalışılmıştır. Kalkınma hedefi çerçevesinde farkl seviyelerde meclisler kurulmuş ve bu meclis üyelerinin seçimle işbaşına gelmesi düşünülmüştür. Ancak bu hedeflere ulaşıldığını söylemek güçtür. Yönetim, uygulamada merkeziyetçi bir anlayışa sahiptir, seçimler yapılamamaktadır, ayrıca yolsuzluk ve liyakatsizlik gibi önemli sorunlar söz

Belediye, konusudur. Genel açıdan Afganistan kamu yönetimi, özelde de yerel yönetimler, oldukça sorunlu bir görüntüye sahiptir.

Keywords:

Afghanistan,

Public

Administration,

Local Governments,

Provincial

Administration,

Municipality,

\section{ABSTRACT}

This study aims to analyze the structure of local governments in Afghanistan. After the US intervention in Afghanistan, the state has been reorganized. This situation has also had a reflection on local government institutions. In Afghanistan, as local governments, there are provinces, districts, municipalities and villages. Furthermore, at the central level, the Independent Directorate of Local Governance also works in the field of local governments. The local governments of Afghanistan have been tried to get structured with the goals of democracy and development. Within the framework of the development objective, parliaments would have been established at different levels, and members of these councils were considered to be elected to work. However, it is difficult to say that these goals have been reached. The administration has a centralized understanding in practice, elections are not held accurately, and there are also important issues such as corruption and incapability. In general, Afghanistan's public administration, in particular the local governments, have a problematic image. 


\section{GIRISS}

Afganistan, resmi adıyla "Afganistan İslam Cumhuriyeti" Asya'da denize kıyısı olmayan dağlık bir ülkedir. Ortadoğu, Orta Asya, Güney Asya, Kafkasya ve Hindistan'ın kesiştiği bir alanda altı ülke ile sınırı bulunan Afganistan; batıdan İran, kuzeyden Tacikistan, Özbekistan ve Türkmenistan, doğudan Çin, güney ve güneydoğudan Pakistan ile çevrilidir. Ülkenin başkenti Kabil'dir. Toplamda $652.100 \mathrm{~km}^{2}$ yüzölçüme sahip ülke, kendi içerisinde üç belirgin bölgeye ayrılır. Kuzeydeki yaklaşık $103.600 \mathrm{~km}^{2}$ lik ova başlıca tarım alanıdır.

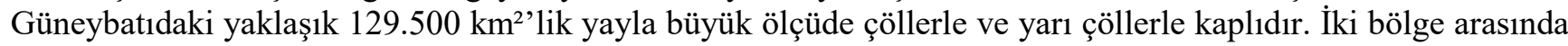
da Himalaya dağlarının uzantısı olan ve Hindikuş Dağlarını da içine alan $414.000 \mathrm{~km}^{2}$ 'lik dağlık yöre yer alır (Saray, 1989:401; Büyükbaş, 2006:54; T.C. Dışişleri Bakanlığ1, http://www.mfa.gov.tr/afganistankunyesi.tr.mfa; Wikipedia Sözlük, https://www.wikipedia.com).

Bozkır ikliminin hakim olduğu Afganistan coğrafyası birbirinden farklı kültürel unsurları birarada bulundurmaktadır. Görüş farklılıkları olmakla birlikte akademik ve tarihi çalışmalar ışığında ülkedeki en eski sakinlerin Amu nehri çevresinde yaşayan Türk'lerin olduğu kabul düşünülmektedir. Sonraki dönemlerde Taciklerin, Peştunların ve diğer kavimlerin bu topraklarda yaşamaya başladığı ifade edilmektedir (Bekmuradi, 2014:12).

Afganistan, coğrafi ve jeostratejik konumu nedeniyle tarih boyunca sürekli göçlere ve savaşlara maruz kalmıştır. Bu sebeple ülke üzerinde farklı etnik kökenler birarada yaşam sürdürmüşlerdir. Ancak savaşlar ve ülkedeki düzensizlikler nedeniyle Afganistan'da 1979 yılından sonra nüfus sayımı yapılamamıştır. Afganistan İstatistik Kurumu'nun 2015 y1lı tahminlerine göre ülkede yaklaşık 32,5 milyon insan yaşadığı düşünülmektedir (T.C. Kabil Büyükelçiliği Ticaret Müşavirliği, 2017:2).

Ülkede yaşayan nüfusun \%42'sini Peştunlar, \%24'ünü Tacikler, \%12.5'ini Türkler, \%8'ini Moğolca konuşan Hazaralar, \%4.2'sini Farisiler (İranlılar), \%3.4'ünü Aymaklar, \%1.7'sini Beluciler kalanını da Paşhailer, Kızılbaşlar, Nuristanlılar, Brahuiler, Hintliler, Ariler, Rajasthaniler, Araplar, Hindular, Pencabiler, Sihler, Darvaziler, Yatlar ve bunların dışında kalan diğer küçük etnik unsurların oluşturduğu belirtilmektedir (Bekmuradi, 2014:14; Blood, 1998:18; https://www.wikipedia.com). İlgili nüfus dağ1lımları kesinlik arz etmemektedir. Farklı kaynaklarda muhtelif oranlara yer verilmektedir. Ülkede düzensizliğin hakim olması nedeniyle nüfus sayımının yapılamaması ülkenin gerçek nüfusunu da ortaya koyamamaktadır. Genellikle seçim sonuçlarına göre tahminler yapılmaktadır. Oldukça sağlıksız koşullarda ve bilimsellikten uzak olarak yapılan nüfus tahmini nedeniyle etnik grupların ayrı ayrı nüfusun ne kadarını oluşturduğu konusunda net rakamlar verilemez (Begzad, 2014:5). Ayrıca ülkede sık sık göçler yaşanmakta ve kargaşa nedeniyle sık ölümler meydana gelmektedir. Afganistan'ın kuzeyindeki kabilelerine Pehtun, güneydekilerine de Peştun denilmektedir. Özbekler ve Tacikler ülkenin kuzey kesimlerinde yaşarken, Hazaralar ülkenin orta kesimlerinde yoğun olarak toplanmıştır. Peştunlar ise güney kesiminde yaygın olarak yerleşmişlerdir. Başkent Kabil, Kandehar, Herat ve Mezar-1 Şerif ülkenin en önemli şehirleridir.

Afganistan'da 70'e yakın dil ve birçok lehçeler konuşulmaktadır. Ancak Farsça ve Peştunca ülkede konuşulan resmi dillerdir. Farsça, ülke genelinde neredeyse tüm etnik gruplar tarafından konuşulabilmektedir. Bununla birlikte Özbek ve Türkmenler ülkenin kuzey kısımlarda kendi dillerini konuşmaktadırlar (Blood, 1998:18). Tacikler, Fars lehçelerinden olan Dari (Tacik) lehçesini konuşurlar. Afganistan ekonomisinin büyük bir kısmını tarım oluşturur. Geri kalan kısmını ise hizmet sektörü oluşturur.

Önceleri İran devletinin bir parçası olan Afganistan ilk defa Mirveys Hotaki önderliğinde bir tür aşiretler konfederasyonu olarak 1709'da kurulmuştur (Andişmend, 2014:54). Hotakiyan adı verilen bu dönemi daha sonra Duraniyan ve Barokzai adı verilen hanedanların dönemi takip etmiştir (Gubar, 2011:14-15).

19. Yüzyılda İngiltere ve Rusya arasındaki rekabete konu olan Afganistan, bir süre İngiliz işgali altında kalıp bağımsızlığını kaybetmiştir. Ancak 1919 yılında Amanullah Han önderliğinde tekrar bağımsızlığını ilan etmiştir. Atatürk'ü kendisine örnek alan Amanullah Han reformist bir yönetim sergilemiştir. Bu dönem de isyan ve iç savaşlar neticesinde sona ermiştir. Bu durumu Rus işgali, tekrar iç savaş, Taliban yönetimi ve ABD işgali takip etmiştir. Böylece ABD işgali sonrasında Hamit Karzai liderliğinde yeni bir dönem başlamıştır. 
YAREE, Tahera - ABD Müdahalesi Sonrasında Afganistan'da İdarenin Yerel Örgütlenmesi: Türkiye Örnekleminde Bir Derğerlendirme

2001 y1lında Bon Anlaşmasıyla birlikte Afganistan'da yeni bir yönetsel dönem başlamıştır (Estanukzay, 2013:150). Yeni dönem, demokratik temellere dayalı yeni anayasa ile perçinlenmiştir. Anayasaya göre Afganistan üniter bir devlettir. Afganistan'da idarenin ülke genelindeki coğrafi kademelenmesi; il, ilçe, belediye ve köy yönetimleri şeklindedir. Hali hazırda Afganistan'da 34 il, 387 ilçe, 165 belediye ve 45587 köy vardır.

Afganistan'da yaşanan iç savaş, ideolojik mücadeleler, siyasal istikrarsızlıklar ve idari kapasite yetersizliği gibi unsurlar modern bir devlet yapılanmasının önüne geçmektedir. Uzun yıllar Rus korkusu ve güdümünde olan devlet yapısı şimdilerde de ABD işgali altındadır. Dolayısıyla da yöneten ve yönetilenler arasında bütünleşmeyi sağlayacak uygun bir siyasi-idari yapı tesis edilememiştir. Devlet yönetiminde yetersizlikler had safhadadır. Ayrıca yönetim araçları ve birimlerinde modern bir yaklaşım ve görev paylaşımı bulunmamaktadır. En basitinden modern devletlerde başkent dişında var olan merkezi idarenin taşra birimleri ile yerel yönetim birimleri arasında kesin bir ayrım ve görev-yetki ayrılığı bulunmamaktadır. Her iki grupta yer alan birimler birbiri ile iç içe geçmiş haldelerdir. Bu sebeple yönetim şemasında ayrı ayrı ele alınmamakta, her iki grupta tek gruba indirgenerek "Yerel Örgütler" adıyla ifade edilmektedirler.

Yerel örgütler, yerel halka hizmet sunmak ve halkın karar verme sürecine katılmasını sağlamak için yetkilendirilmişlerdir (An.md.137). Merkezi hükümet ve yerel yönetim birimi arasındaki ilişki hiyerarşi modelini temel almaktadır. Daha yalın bir ifade ile yukarıdan aşağıya doğru bir bağ ile gitmektedir. Bu yönüyle Afganistan merkeziyetçi bir devlet olup, bütün güç merkezi hükümetin elindedir. İl ile ilçelerin yetki ve sorumlulukları merkezi hükümet tarafından belirlenmektedir. İller ve ilçeler yerel yönetim birimleri olmalarına rağmen, uygulamada özerk değillerdir ve karar verme yetkileri de bulunmamaktadır (Afganistan Yerel Yönetim Politikası, 2010:87). Yine Köy'lerin tüzel kişiliği bulunmamaktadır. Ülkedeki ilçe sayılarında kesinlik yoktur. Resmi olmayan ilçeler bulunmaktadır. Dahası ilçelerin sınırları kesin olarak belirlenememiştir. Bu nedenle bir ilçenin kesin idari sınırları ve bu sınırlar içerisinde yaşayan toplam nüfusu tespit edilememektedir. Daha sınırı bile kesinleşmemiş olan bir idari birimin bu sınırlar içerisinde modern kamu hizmetlerini sunması beklenemez. Mevcut düzensizlikler ve yeterizlikler nedeniyle yerel örgütlenmeler il düzeyinden koordine edilmeye ve yönetilmeye çalışılmaktadır.

Ülkedeki belediyeler modern yerel yönetim birimi olmaktan oldukça uzaktır. En başında belediye başkanlarının seçimle göreve gelmesi kanunla ortaya konulmuşken, şu ana kadar bu yönde herhangi bir seçim yapılmamıştır. Belediye başkanları halkın seçmesi ile değil merkezi idarenin ataması ile göreve gelmektedirler. Bununla birlikte, belediyelerin sundukları kamu hizmetleri yerel düzeyde elde ettikleri gelirler ile sınırlıdır. Ayrıca ülkedeki belediyelerin 1/6'sı da savaş ve diğer bazı sebeplerle aktif değildir. Afganistan'da Bakanlar Kurulunun (merkezi idarenin) taşradaki görevlerinin uygulanmasında belediyelerin de görev aldığı görülmektedir. Oysa ki bu görev ve yetkinin merkezi idarenin taşra birimleri (il, ilçe gibi) tarafından yapılması gerekmektedir. Buradan hareketle Afganistan'da ilk başta terminolojik açıdan ve kara avrupası yönetim sisteminin farklı ülkelerdeki uygulamaları açısından il ve ilçe birimleri merkezi idarenin taşra birimlerini yansıttığı düşünülebilir. Aynı perspektifle belediyelerin de birer yerel yönetim birimi olduğu kanaati uyanabilir. Ancak tüm bu idari birimlerin hukuki yapısı, görev ve yetkileri ile birbirleri ve merkezi idare ile olan ilişkileri incelendiğinde böyle bir ayrımın yapılamayacağı anlaşılmaktadır. İç savaş, işgal, gelenekler, idari kapasite yetersizlikleri ve siyasal istikrarsızlıkların etkisiyle ülkede modern bir yönetim sistemi kurulamamış ve idareler/kurumlar iç içe girmiş halde varlıklıklarını devam ettirmişlerdir.

ABD'nin Afganistan'a müdahalesinden sonra yeni bir sistemin kurulduğu ve bu sistemin daha ziyade bir yardım ekonomisi olduğu söylenebilir. Ülkede mevcut olan nitelikli kadronun neredeyse tamamının yüksek maaş ve iyi yaşam koşullarıyla özel sektöre taşındığı bilinmektedir. $\mathrm{Bu}$ yardım ekonomisi adı altındaki girişimler, başlangıçta ülkenin ilerlemesini sağlamakla birlikte, sonrasında özel sektöre geçişlerdeki artış ve kamudaki nitelikli kadronun azalmasına, dolayısıyla da mevcut düzenin olumsuz etkilenmesine katkı sağlamıştır. Böylelikle de ülkedeki kamu yönetimi sisteminde istenilen iyileşme bir türlü sağlanamamıştır (Rahmani, 2015:213). Bu durum kamu sektörünün nitelikli personel açığına sahip olması şeklinde sistematik bir problem oluşturmaktadır. Bu problemin yanı sıra Afganistan bürokrasisinin yetersizliği de ülkedeki yönetim sisteminin gelişiminin en önemli engellerinden birisidir. Afganistan'da yerel yönetimlerin güçlenmesinin ve daha iyi hizmet sunmasının önündeki en önemli engellerden bir diğeri de yerel yönetimlerle ilgili sistemli politika eksikliğidir.

Bu çalışmanın amacı; Afganistan'da ABD müdahalesi sonrasında oluşan devlet yapılanması içinde idarenin yerel örgütlenmesini incelemektir. Bu çerçevede önce kısa bir tarihi süreç anlatılmıştır. Sonrasında da yerel yönetimlerle ilgilenen merkezi kuruluş olan Bağımsız Yerel Yönetim Müdürlüğü ve yerel yönetim kuruluşları olan il, ilçe, belediye ve köy yönetimleri analiz edilmiştir. 
Afganistan'da yerel yönetimlerin yapısının ve işleyişinin incelenmesi, modern devletin kurumsallaşması ve geleneksel toplumsal yapı içerisinde tesis edilmeye çalışılması bağlamında önemlidir. Nitekim Afganistan'ın toplumsal yapısı uzun tarihi boyunca şekillenirken, modern devletin ve bununla bağlantılı olarak modern yerel yönetim birimlerinin tesisi yabancı devletlerin işgalleri ve yerli reformcuların çabaları bağlamında daha kısa vadeli süreçlerle gerçekleştirilmeye çalışılmıştır. Üstelik bu süreç devamlı olarak iç savaşlar ve geriye dönüşler ile akamete uğramış ve bu sebeple modern devletin kurumsallaşması sürekli tehir edilirken bu istikrarsılık içinde geleneksel toplumsal yapı baskın karakterini devam ettirmiştir. Bütün bunlar bir arada düşünüldüğünde Afganistan tecrübesini analiz etmenin modern devlet-geleneksel toplum ve yerel yönetimler üçgeni çerçevesinde ilginç ve önemli bir yönü olduğu açıktır.

Bu çalışmada Afganistan'ın yerel yönetim birimlerinin incelenebilmesi için yerel kaynaklar -daha ziyade Farsça metinler- analiz edilmiştir. Bunlara ilaveten yerel yönetimlerin hukuki çerçevesini oluşturan düzenlemeler çalışma kapsamına alınmıştır. Ayrıca bu hukuki düzenlemelerin ne şekilde uygulandığı mevcut siyasi gerçeklik göz önüne alınarak yorumlanmıştır.

İller, ilçeler ve köylerin bazı ortak görevleri vardır. Bu ortak görevler; barış ve güvenliği sağlamak, yerel halka hizmet sunmak, sosyal kalkınmayı sağlamak, ekonomik ve kültürel gelişmeyi sağlamak, doğal afetler ve olaylarla mücadele için çabalamak, uyuşturucuları ortadan kaldırmak ve diğer görevlerdir (Teşkilat Esası Kanunu, md.35-48)

Afganistan'da yerel örgütlerin temel yapısını ele almadan önce, bu yapıların bağlı bulunduğu merkezi idare (başkent örgütü) ve bu idare içerisinde yer alan "Bağımsız Yerel Yönetim Müdürlügü" hakkında bilgi verilmesi konunun anlaşılması açısından yararlı olacağı düşünülmektedir. Özellikle merkez ile yerel örgütler arasında bir bağ görevi gören ve modern devlet yapılarında pek fazla alışkın olunmayan bu yapının ele alınması, ülkedeki genel tablonun ortaya konmasına katkı sağlayacaktır.

\section{AFGANISTAN'DA DEVLET YÖNETIMINI OLUŞTURAN GÜÇLER}

Afganistan'ın idari yapısı merkezi ve yerel örgütlere ayrılmıştır (An.md136). Afganistan'ın mevcut olan anayasası 1964 yılındaki anayasaya dayanmaktadır. Afganistan, idari sistemini Fransa modelinden almıştır. Afganistan'da Millet ve Senato meclisi vardır. Millet meclisi üyeleri beş yıl için doğrudan halkın içinden ve halk tarafından her ilden seçilir. Millet ve Senato meclisleri toplumun gelişmesi için ekonomik, sosyal ve teknolojik konulara dair görevlerini komisyonlar aracığıyla yürütmektedir. Yasamanın diğer önemli görevi gensorudur. Millet Meclisi vekili bakanları gensoruyla görevden alabilecek yetkiye sahiptir. Yargı organı Afganistan'ın yargısından sorumludur. Yargıçların başkanı Afganistan'ın yargı organının başkanıdır. Yargı organı Yüksek makeme, temyiz ve ilke mahkemesinden oluşmaktadır (An.md116).

Afganistan'ın Yargı mahkemelerin teşkilatı kanunla düzenlenir. Yüksek mahkeme kanun eleştirme konusunda geniş yetkileri sahiptir. Örneğin Kanun, düzenlemeler, sözleşmeler, uluslararası sözleşmeler kanuna uygun veya uygun olmaması teşhisi yüksek mahkemenin görevidir. Merkezi yönetim birimlere ayrılır ve her birimi bir bakan tarafindan yönetilmektedir.

Yeni anayasada cumhurbaşkanı ve bakanlar, yürütmenin en önemli aktörleridir. Cumhurbaşkanı beş yıl için vatandaşların oyuyla seçilir. Cumhurbaşkanı, ülke yönetimindeki üst düzey kamu görevlilerini görevlendirir ve görevden alır. Yönetimde karar alma cumhurbaşkanı tarafından ve meclis onayı ile gerçekleşmektedir. Yeni düzende Afganistan'ın genç nüfusuyla da ilişkili olarak yeni kurumlar ihdas edilmiştir. Bu kurumlar cumhurbaşkanlığı kararnamesiyle özel görevler için kurulmaktadır. Bu kurumların amacı bakanlıkların görevlerinin daha iyi olması için çalışmaktır. Kurulan kurumlar yürütme gücünün bir parçasıdır. Ancak bakanlar kurulu üyesi değildirler. Bu kurumlar doğrudan cumhurbaşkanına bağlılardır.

Merkez Bankası, Başsavcı, Bağımsız İdari Reform Komisyonu, Bağımsız Seçim Komisyonu, Bağımsız İnsan Hakları Komisyonu, Yolsuzlukla Mücadele Kurumu, Merkezi Genel Nüfus Sayımı, Denetleme ve Kontrol Müdürlüğü kararname ile kuruldular. Afganistan devlet yapısı içindeki yeni kurumlardan bir tanesi özellikle de yerel yönetimler bağlamında önemli olan Bağımsız Yerel Yönetim Müdürlüğü'dür. 


\section{BAĞIMSIZ YEREL YÖNETIM MÜDÜRLÜĞÜ}

Bağımsız Yerel Yönetim Müdürlüğü, teşkilat yapısı ve görevleri bağlamında Türkiye'de ve benzer ülkelerde olmayan bir yönetim kurumudur. Afganistan uzun süre savaşla yaşamış bir ülke olduğu için ülkenin yeni sistemi ABD müdahalesiyle en temelinden başlamıştır. Ülkede uzun yıllar süregelen savaşlar ve sık sık yaşanan rejim değişiklikleri halkın yönetimde yapılan her alandaki yenilikleri benimsemesini zorlaştırmıştır. Dolayısıyla merkezi yönetim ve yerel yönetimin daha verimli olması için kurulan bu kurum halk ile yönetim arasında bir köprü görevi görmektedir. Bağımsız Yerel Yönetim Müdürlüğü, yerel yönetimlerle ilgilenmek üzere Cumhurbaşkanı kararnamesi ile kurulmuştur. Görevi, ülkedeki idari mevzuatı uygulamaktır. Müdürlügün memurları merkez ve illerde birçok alanlarda çalışmaktadır. Bağımsız Yerel Yönetim Müdürlügü; 34 il, 364 resmi ve gayri resmi ilçe ve 153 belediyede ilgili birimleri vasıtasıyla programlarını uygulamaktadır (Bağımsız Yerel Yönetim Müdürlüğü, http://idlg.gov.af/fa/page/idlg/history).

Bağımsız Yerel Yönetim Müdürlüğü, ulusal ve yerel düzeyde, bağımsız, egemen, şeffaf, hesap verebilir, katılımcı, etkili ve yaygın yönetimi sağlamak için iller, ilçeler ve belediyelerin gücünü arttırmakla yükümlüdür. Daha yalın bir ifadeyle Bağımsız Yerel Yönetim Müdürlügü; valilerin, kaymakamların, seçilmiş meclislerin ve belediyelerin görevlerini kolaylaştırır. İl, ilçe, belediye ve köy düzeyindeki devlet kurumları yerel halka yerel meclisler yoluyla hesap vermektedir. Bu noktada il düzeyinde il meclisi, ilçe düzeyinde ise ilçe meclisi bulunmaktadır. İl ve ilçedeki bakanlıkların temsilcileri, emniyet teşkilatı, mustufiyet (defterdar) kurumu ve kaymakamlar valiye karşı sorumludur. İlçe düzeyindeki bakanlık temsilcileri, kaymakam ve ilçe meclisine hesap vermektedirler (Bağımsız Yerel Yönetim Müdürlüğü, http://idlg.gov.af/fa/page/idlg/history).

Yerel yönetim kuruluşlarının temel amaçlarını; şeffaf, müşterek, hesap verebilir ve etkili yönetimin sağlanması, kanunların yerel düzeyde uygulanması, yerel halkın yönetime katılması için yerel kurumların oluşturulması, bu kurumlara destek verilmesi, vatandaşlara hizmet sunmak amacıyla onların hakkının korunması, yerel yönetişime vatandaşın katılımı için firsatlar yaratılması, yerel yönetim kuruluşlarının faaliyetlerinin düzgün bir şekilde yerine getirildiğinin denetlenmesi, vb. şeklinde sıralayabiliriz (Bağımsız Yerel Yönetim Müdürlüğü, http://idlg.gov.af/fa/page/idlg/history).

Bağımsız Yerel Yönetim Müdürlüğü'nün politika alanındaki temel görevi; yerel yönetimlerle ilgili kural ve düzenlemelerin politika çerçevesini tasarlamaktır. İdari geliştirme alanındaki temel görevleri ise, yerel kurum ve kuruluşlara destek olarak onların yeteneklerini geliştirmesine katkı sağlamaktır. Yönetim ile ilgili görevleri ise, vatandaşlar ve diğer ortakların yönetim sürecine katılımı için destek sağlamaktır. Yerel organlar aracılığıyla planlar yapması ve ulusal yenilikleri kolaylaştırması da destek görevlerindendir (Bağımsız Yerel Yönetim Müdürlügü, http://idlg.gov.af/fa/page/idlg/history).

\section{AFGANISTAN'DA İDARENIN YEREL ÖRGÜTLENMESİ}

Afganistan'da, merkezi idarenin taşra birimleri ile yerel yönetim birimleri iç içe geçmiş bir haldedir. Bu nedenle merkezi idareye bağlı yalın taşra birimleri ile asgari düzeyde özerkleşmiş yerel yönetim birimleri ülkede bulunmamaktadır. Ağırlıklı olarak merkezi idarenin taşra birimi görüntüsüne sahip, bununla birlikte bazı yerel yönetimlere özgü özellikler ile donatılmış bir yerel örgütlenme yapısı ile karşılaşılmaktadır. Bu nedenle, zorunlu olarak taşrada yer alan tüm idari birimler tek bir ana başlıkta ve birlikte ele alınmıştır.

Afganistan'da yerel örgütlenmelerin yapılanmasında roller ve ilişkiler belirsiz ve tutarsızdır. Bu durum, kurumların görevlerini yerine getirmesine ve daha iyi hizmet sunmasına engel teşkil etmektedir. Hesap verebilirlik mekanizması yerel düzeyde çok zayıftır. Devlet kurumlarının görevlerini yerine getirmesi için yeterli altyapı bulunmamaktadır. Örneğin 34 ilin bulunduğu ülkede 29 adet valilik binası bulunmaktadır ve 34 validen sadece 15'ine devlet tarafından konut sağlanmaktadır (Afganistan Yerel Yönetim Politikas1, 2010:100). Valilik seviyesinde bile bu sorunlar mevcut iken ilçe, belediye ve köy düzeyinde kaynakların yeterli ve etkin olduğu düşünülemez.

Taşralardaki İl yöneticileri, illerde planlama veya bütçeleme konusunda çok az yetkiye sahiptirler. Başka bir deyişle, bakanlıklar merkezde yetkiyi elinde bulundurmaktadırlar. İllerde yer alan kuruluşlar üç aylık mali harcamalarını, bakanlıklarca belirlenen bütçelerinden yaparlar. Bu nedenle il yönetimi finansal açıdan özerk değildir. İl yönetimi ayrıca idari örgütlenme ve personel yönetimi gibi konularda da özerk değildir. Kamu çalışanlarının işe alınması, istihdamı ve tayini gibi konularda il yönetimlerinin sembolik bir rolü bulunmaktadır. 
İl yönetiminin kurumsal yapısı merkezi hükümetçe belirlenmektedir. İllerdeki kamu personeliyle ilgili kararların çoğu başkentte yer alan bakanlıklar tarafindan ve idari reform komisyonu, Kamu Hizmeti Kurumu ile Bağımsız Yerel Yönetim Müdürlüğ̈̈'nün tavsiyesiyle alınır.

Yerel örgütlenmelerin merkeze bağlı ve demokratiklikten uzak yapısı, yerel örgütler içerisinde yer alan birimlere de yansımıştır. Yerel düzeydeki şûraların rolü genel olarak danışma rolünde kalmaktadır. Yaptırım gücü pek fazla bulunmayan bu yapılanmalar, merkezi hükümete karşı oldukça zayıf yetkilere sahiplerdir (Ahmady, 2015:189). Afganistan'daki yerel örgütlenmeler "il", "ilçe", "belediye" ve "köy" olarak dört ana başlik altında ele alınmaktadır.

\section{1. İl Yönetimi}

Afganistan'da en önemli ve etkin olan yerel örgütlenme birimidir. Vali tarafindan yönetilen illerde il idari meclisi, il meclisi, il geliştirme komitesi ve bakanlıkların il düzeyindeki temsilcilikleri il yönetimi kapsamında yer almaktadır.

\subsubsection{Vali}

Valiler, il düzeyinde yürütmenin başıdır. $\mathrm{Bu}$ nedenle merkezden gelen emir ve talimatları yerel idarelere iletmektedirler. Resmi olarak ildeki kurumlar arasındaki koordinasyonun sağlanmasından sorumludurlar. Valiler, devlet başkanı tarafından atanır ve yine devlet başkanı tarafından görevden alınır. Valiler, görevlerini il idare meclisi ve il geliştirme komitesi ile birlikte yürütürler. Türkiye'de ise vali, kanunlarda belirtilen görevleri yerine getirmek ve merkezden gelen emirleri mevzuat kapsamında uygulamaktan sorumludurlar. Valilerin Türkiye'deki görevi çift yönlüdür. Bir yandan merkezi idarenin üst taşra birimi olan il genel idaresinden sorumludurlar. Bu onların temel görevidir. Bununla birlikte bir yerel yönetim birimi olan il özel idaresinin de başıdır. Türkiye'de valilerin il özel idaresi ile ilgili temel görevi; il genel meclisi ve il encümeni tarafından alınmış kararları uygulamalarıdır (Eryılmaz, 2013:186). Temsil ve yürütme organlarına başkanlık ederler.

Afganistan'da İl geliştirme komitesi, il planlarının yapılmasından sorumludur. Kanuna göre valiler devlet başkanı ile Bağımsız Yerel Yönetim Müdürlüğü'ne karşı sorumludurlar. Ülkede valilik, idari ve siyasi açıdan önemli bir makam olarak kabul edilmektedir (Tamaki, 2011:273).

\subsubsection{Valilerin Görev ve Sorumlulukları}

Vali ildeki en yüksek idari temsilci ve yerel yönetimden sorumlu olarak çeşitli görevlere sahiptir. Valinin görevleri idari, siyasi ve güvenlikle ilgili olanlar şeklinde üçe ayrılabilir. Afganistan'da tüm valilerin nitelikleri yasal açıdan aynıdır. Ancak valilerin fiili gücü o ildeki kabile ilişkilerine göre önemli farklılıklar gösterebilmektedir. Örneğin nüfusun Peştun ağırlıklı olduğu bir ilde vali de Peştun ise yoğun kabile ilişkileriyle orantılı olarak vali çok fazla güce sahip olabilir.

İl düzeyinde valilerin görevi şunlardır (Afganistan İdare Mahali Kanunu, md.14):

- Barış, güvenlik, kamu düzeni, kanun egemenliği ve insan haklarının korunmasının sağlanması. Uyuşturucu ile mücadele, yoksulluğun azaltılması, merkezi ve yerel yönetimlerin faaliyetleri arasında koordinasyon kurulması, kamu işlerinin düzenlenmesi ve finansal yönetimin iyileştirilmesi vd.

- Valiler siyasi sorumluluklara da sahiptirler. Vali siyasi görevlerini il düzeyinde karar alma ve yasaları uygulama yoluyla yürütmektedir. Bu bağlamda vali yabancı uyrukluların giriş ve çıkışını kontrol eder, il düzeyinde siyasi konsolosluklar ve siyasi temsilciler ile iletişim kurar. Vali ildeki kurumlar arasında uyumun sağlanması ve ildeki kurumların ve bu kurumlarda çalışanların performans ve denetiminden sorumludur. Ayrıca vali vatandaşların özgürlüklerinin korunması ve seçim güvenliğinin sağlanması konusunda gerekli işbirliğini yapmaktadır. Türkiye'de de vali aynı görevlere sahiptir. İl geliştirme toplantıları ayda bir kez vali başkanlığında yapılır. Bu toplantıların amacı il planlaması ve mali denetimdir.

- Vali, ildeki gelişmeleri Bağımsız Yerel Yönetim Müdürlüğü'ne rapor eder.

- Vali yerel kurumların vatandaş ve il meclisine hesap vermesi sürecini kontrol etmektedir. Böylece eğer vatandaşlar kurumlardan memnun değilse bu kurumları vali ve il meclisine şikâyet ederler (Afganistan Yerel Yönetim Politikası, 2010:123).

- Valiler ilçelerdeki çalışmaları, ildeki kurumları, ilin günlük işlerini ve çeşitli konuları merkeze raporlarlar. Halkın huzur ve güveninin sağlanması, çalışanların atanması, gelişim planlarının izlenmesi, 
YAREE, Tahera - ABD Müdahalesi Sonrasında Afganistan'da İdarenin Yerel Örgütlenmesi: Türkiye Örnekleminde Bir Derğerlendirme

ildeki bütçe ve harcamaların izlenmesi gibi konularda liderlik yapar ve ilde hükümeti temsil eder (Tamaki, 2011:274).

- Vali, acil durumlarla mücadele komitesinin başkanıdır. Bu komite il düzeyinde doğal afetlerden doğacak zararların azaltılması için hazırlık, acil müdahale ve yeniden yerleşim faaliyetlerini denetlemek ve yönetmekten sorumludur.

- Düzeni korumak ve güvenliği sağlamak devletin ana görevidir. Vali, ilde hükümetin temsilcisi olarak düzeni korur ve güvenliği sağlamaktan sorumludur. Böylece vali emniyet güçlerinden de sorumlu bir yöneticidir (Polis Kanunu, md.4).

Valiler yasa gereği yukarıda saydığımız görev ve yaptırım gücüne sahiptir. Kanunlarda görev tanımı bu şekilde belirtilen valiler uygulamada ise ilde yasa ve kuralların gösterdiğinden çok daha fazla güce sahip olabilmektedir. Bazı valilerin kimi zamanlarda kurallara aykırı olarak insanları işten çıkardığı ya da atama yapabildiği görülmektedir. Bu durum hala Afganistan'da hukuk devletinin yeteri kadar işlerliğinin olmadığını ortaya koymaktadır. Bu aynı zamanda Afganistan'ın geçmişi ile ilgili bir durumdur. Nitekim geçmişten gelen aşiret ilişkileri ve kişisel özellikler Afganistan'da hala önemli bir değişkendir.

Türkiye de ise valiler benzer görevler ve yetkilere sahiptir. Kanuna göre valinin il özel idaresi nezdindeki görevleri şunlardır (5302 Sayılı Kanun, md.30);

- Il özel idaresi teşkilatının en üst amiri olarak il özel idaresi teşkilatını sevk ve idare etmek, il özel idaresinin hak ve menfaatlerini korumak.

- Il özel idaresini stratejik plana uygun olarak yönetmek, il özel idaresinin kurumsal stratejilerini oluiturmak, bu stratejilere uygun olarak bütçeyi, il özel idaresi faaliyetlerinin ve performans ölçütlerini hazırlamak ve uygulamak, izlemek ve değerlendirmek, bunlarla ilgili raporları meclise sunmak.

- Il özel idaresini devlet dairelerinde ve törenlerde, davacı veya davalı olarak da uyarı yerlerinde temsil etmek veya vekil tayin etmek.

- Il encümenine başkanlik etmek.

- Il özel idaresinin taşınır ve taşınmaz malların idare etmek.

- Il özel idaresinin gelir ve alacaklarını takip etmek.

- Yetkili organların kararını almak şartıyla sözleşme yapmak. İl genel meclisi ve encümen kararlarını uygulamak.

- Il halkının huzur, esenlik, sağglk ve mutluluğu için gereken önlemleri olmak.

- Kanunlarla il özel idaresine verilen ve il genel meclisi veya il encümeni kararını gerektirmeyen görevleri yapmak ve yetkileri kullanmak.

\subsection{2. İl İdari Meclisi}

Afganistan'da İl meclisi 1964 yılında kuruldu. Bu meclisin kuruluş amacı, vali başkanlığında bakanlıkların ildeki temsilcileri arasında bir koordinasyon mekanizması oluşturmaktır. İdari meclisin üyeleri; vali, vali yardımcıs1, mustufi (ildeki maliye bakanlığı temsilcisi), il emniyet müdürü, saranvallar (savcılar) ve ildeki kamu kurumlarının başkanlarıdır. Eğer meclis davet ederse kaymakamlar da toplantılara katılabilirler. İl idari meclisi her hafta toplanır. İl idari meclisinin kararları toplantıya katılanların salt çoğunluğu ile alınır. İl idari meclisinin görevleri şunlardır: devlet arazilerinin kiralanması ve satılması, devlet borçlarının taksitlere bölünmesi. ìl geliştirme şûrası ile birlikte il idari meclisi önemli bir role sahiptir. Çünkü her iki meclis de kurumları koordine etmekten sorumludur. İl idari meclisi idari işlerin koordinasyonundan sorumlu iken, İl geliştirme şûrası kalkınma işleri ile görevlidir. İl idari meclisi, ilin kalkınma planlarının uygulanmasından sorumludur. Fakat, bu planların tasarlanması, bütçelendirilmesi ve planlar ve bütçeler arasında ilişki kurulması il geliştirme şurasının görevidir. İl idari meclisi her hafta toplantı yaparken, il geliştirme şûrası ayda bir kez toplantı yapar. İl idari meclisi ve il geliştirme şûrası, İl meclisi aracılığıyla vatandaşlara hesap verirler. 


\subsection{3. İl Meclisi}

Afganistan il meclisi yasalara göre, il düzeyinde üyeleri halk tarafından seçilen tek kurumdur. Afganistan İl Meclisi Kanunu'nun 2. maddesine göre il düzeyinde halk ve sivil toplum örgütlerinin devlet yönetimine katılabilmesi için il meclisi kurulmuştur. Afganistan hükümeti il meclisinin etkin bir role sahip olması için çabalamaktadır. Ancak bu doğrultuda hiçbir seçim yapılmamıştır. Yönetimdeki temel zorluk halk ve hükümet arasındaki mesafe ve güvensizliktir. Yöneticilere ve kurumlara erişim eksikliği halk arasında memnuniyetsizliğe neden olmaktadır. Merkezi hükümet bu meclislerin güvenlik, siyasi ve yeniden yapılanma alanlarında yerel yönetimlerle daha iyi bir işbirliği yapmasını sağlamak için çalışmaktadır. 34 ildeki il meclisleri küçük parlamentolar gibidir. Valiler, kaymakamlar ve diğer kamu kurumlarının başkanlarının faaliyetlerinin izlenmesi il meclisinin temel yetkilerinden birisi iken zamanla yasa sadece mali konularda il meclisine izleme yetkisi vermektedir (Siret, 2014:1). Fakat bu yetkinin uygulanabilirliği de günümüzde oldukça sorunludur. Hatta yok denecek kadar azdır. Çünkü il meclisinin gücü valinin gücüne kıyasla daha azdır. Buradaki temel sorunlardan birisi valilerin merkezden atanıp, merkeze karşı sorumlu olmasıdır. Nitekim vali il meclisine hesap vermek zorunda değildir. Çünkü valiler asıl itibariyle başkana ve bağımsız yerel yönetim müdürlügüne karşı sorumludur. Burada esas olan il meclisinin politik gücünü arttırmaktır. Bu gerçekleştiği takdirde valilere ve hatta merkezi hükümetin kararlarına dahi karşı durulabilir (Arvin, 2015:1).

İl Meclisinin Görevleri Şunlardır (Mohhamady, 2014:1):

- Ekonomik, sosyal, sağlık, eğitim ve çevre programlarının geliştirilmesine katılmak ve illerde geliştirme planlarını yapmak.

- İldeki kamu kurum ve kuruluşlarının vatandaşlara hesap verebilirliğini sağlamak.

- Bakanlıkla bağlı taşra müdürlüklerinin faaliyetlerini izlemek.

- İl geliştirme planı ve bütçe yapımına katılmak.

- Valiler tarafindan meclise sunulan aylık faaliyet raporunu değerlendirmek, uygun bulunmaması halinde Bağımsız Yerel Yönetim Müdürlügü’ne ve Cumhurbaşkanına şikâyette bulunmak.

- Halk tarafından yapılan kamu şikâyetlerini incelemek ve bu hususta valilik ile bakanlık taşra teşkilatlarından alınan bilgiler ile vatandaşlara cevap vermek.

- Yerel sorunları ve aşiretler arasındaki ihtilafları Cerge (Geneleksel meclis) aracılığıyla çözüme kavuşturmak.

- Vali ve devlet kurumları ile aylık danışma toplantıları düzenlemek.

- Ulusal egemenlik yapısında yerel halkın ana temsil organı olması dolayısıyla en az üç ayda bir yerel halklar ile danışma toplantıları düzenlemek.

- Yerel barışın sağlanması, kanun egemenliğinin tesisi, insan halklarının geliştirilmesi ve huzurun sağlanması faaliyetlerine katılmak.

- Zorla evlilikler gibi şeriata aykırı adet ve geleneklerin kaldırılmasına katkı sağlamak.

- Uyuşturucu imalatı, satışı ve depolanması ile uyuşturucu kaçakçılığının önlenmesi amacıyla halka bilgi vererek halkın uyuşturucuyla mücadelede aktif katılımını sağlamak.

- Kültürel ve tarihi eserlerin korunmasına dikkat çekmek.

- Devlet ve kamu varlıklarının gasp edilmesini önlemek.

- Afganistan ulusal geliştirme stratejisinin uygulanmasına katılmak.

- Çevre koruma ve doğal afetler konularında katkıda bulunmak.

Türkiye'de ise il genel meclisi görevlerini yerine getirmek için gerekli yetkiye sahip olduğunu söyleyebiliriz. Türkiye'de il genel meclisi ihdas, yatırım, borç vermek veya almak konusunda karar alabilir. Başka bir deyişle Afganistan'da il meclisi katılımcı ve izleyici olarak çalışmakta iken, Türkiye'de il genel meclisi il halkıyla ve gerekli kurumlarla görüşüp karar verme yetkisine sahiptir. 


\subsection{4. İl Geliştirme Komitesi}

2005 yılında cumhurbaşkanlığ kararnamesi ile "İl Geliştirme Komitesi" kurulmuştur. İl geliştirme komitesi planlama kurumu, bütçeleme ve sektörlerin birliği konularında faaliyetlerini yapmaktadır. Bu komitenin toplantıları ayda bir yapılmaktadır. Vali, il geliştirme komitesinin meclis genel başkanıdır. İl meclis başkanı, ildeki bakanlıkların temsilcileri ve başkanların il geliştirme komitesinin toplantılarına katılması zorunludur. İl geliştirme komitesi ve İl idari meclisi, il düzeyinde planlama ve koordinasyonun gerçekleştirmesi için yetkili kurumlardır. İl geliştirme komitesi vali tarafından yönetilmektedir. İl geliştirme planları, yatırım stratejileri, uyuşturucu ticaretinin kaldırılması, ilgili faaliyetlerin izlenmesi il geliştirme komitesinin görevleridir. İl geliştirme komitesi, il meclisinin işleyişini kolaylaştırmak için var olan bir kurumdur. Bu nedenle, hesap verme zorunluluğu yoktur. Ancak, il geliştirme komitesi ve Maliye Bakanlığı arasındaki görev tanımının belirsizliği, bu iki kurum arasında zaman zaman anlaşmazlıklara neden olmaktadır.

Türkiye'de bu organın adı il encümenidir. İl encümeni, il geliştirme komitesi gibi stratejik plan, y1llık çalışma ve bütçe konularında çalışmaktadır. Türkiye'de il encümeni; ilin gider, vergi ve hemen hemen bütün mali işlerini yapmaktadır (Koçak, 2013:164).

\subsubsection{Bakanlıkların İllerdeki Temsilcileri}

Bakanlıkların illerdeki temsilcilerinin ana görevi, ilgili hizmetlerin sağlanmasıdır. Her bakanlık, il ve ilçeler için gerekli kaynakları ve yetki devrini öngören uygun bir politika önerisini hazırlamalıdır. Bu amaçla merkez ile il arasında görev ve yetki bölüşümü olmalıdır. Böylece hizmetin kalitesi ve etkinliği artacaktır. Siyasi kararlar ve politika önerileri merkezden alınmaktadır. Ancak yetki devri ile su ve kanalizasyon, sağlık işleri, eğitim, ulaşım, yerel taşımacılık, kentsel ve kırsal alt yapı, tarım ve sulama, doğal kaynak yönetimi, arazi kaydı, sosyal güvenlik, kimlik kartı dağıtılması, eğlence tesisleri, kütüphane vb. konular il, ilçe ve belediyelere birakilmaktadır.

Bakanlık temsilcilerinin rol ve sorumlulukları ile ilgili diğer hususlar şu şekilde sıralanabilir (Afganistan Yerel Yönetim Politikas1, 2010:155-156):

- Hükümet her yıl valiler ve bakanlık temsilcileri arasında daha fazla işbirliği için konferanslar düzenler.

- Merkezi bakanlıklar, il ve ilçedeki bakanlık temsilcileri çalışma kapasitesi ve yetki devri için kapasite geliştirme programı yürütürler.

- Bakanlık temsilcileri faaliyetlerini il meclisine rapor halinde sunar.

- Bakanlık temsilcileri, il meclisi, il kalkınma meclisi ve valiler ile kapsamlı bir şekilde işbirliği yapmalıdır.

- Bakanlık temsilcileri il düzeyinde cinsiyet eşitliğini destekler.

\section{2. İlçe Yönetimi}

İlçe, birkaç köyden oluşan bir idari birimdir ve kaymakam tarafından yönetilmektedir. İlçenin merkezi, ekonomik, sosyal, kültürel ve coğrafi durumuna göre belirlenir. İlçelerin dereceleri kaymakamların yetkisini etkilemez. Bir ilde en az üç ilçe olmak durumundadır. İlçe sayısı olarak üst sınır yoktur. Kaymakamın mali kaynakları Bağımsız Yerel Yönetim Müdürlüğü tarafından valilik ofisi aracılığıyla sağlanmaktadır.

\subsubsection{Kaymakam}

İlçede kaymakam en yüksek idari yetkilidir ve yürütme yetkisini haizdir. Kaymakamlar serbest rekabet ve sınav süreci ile seçilir. Kaymakamların atama ve tayinleri merkezi hükümet tarafından yapılır. İlçe düzeyinde kaymakam, planlama faaliyetlerini yönetir, idari işlerin bütçelenmesi ve koordinasyonunu yapar. Ayrıca kalkınma ve güvenlik konularından sorumludur. Kaymakamlık merkezi hükümetin en alt birimidir. Bu sebeple kaymakamlar bizzat vatandaşların dilekçesini doğrudan alır ve çözer. Kaymakamlar resmi şekilde valilere rapor vermelidirler. Yerel yönetimler yasasının 4. maddesine göre, kaymakamın yetkileri ile valilerin yetkileri arasında bir fark yoktur. Ancak uygulamada kaymakamlar valilerden daha az yetkiye sahiptirler. Belirtilmesi gereken önemli bir husus, ilçede kaymakamın yürütme organının temsilcisi olmadı̆̆ıdır, bu açıdan siyasi otorite sayılmazlar ve merkezi hükümetin yetkilileri ile iletişim kurmazlar. Kaymakam valiye karşı sorumludur ve bütün işlerde onunla uyumlu çalışır (Tamaki, 2011:277). Türkiye'de her ne kadar kaymakamlar valiye karş1 
sorumlu olsalar da ilçe düzeyindeki merkezi idarenin temsilcisi konumunda olan şube müdürleri ile ilişkilidir. Onların amiri pozisyonunda olup, aralarındaki koordinasyon ve denetiminden de sorumludur.

İlçe düzeyinde kaymakamların temel sorumlulukları şunlardır; Barışın sağlanması, güvenlik, kamu düzeni ve istikrarı ile kanun egemenliğinin sağlanması, insan haklarının desteklenmesi ve geliştirilmesi, doğal afetlerin yönetimi, uyuşturucu ile mücadele, merkezi ve yerel kurumların faaliyetleri arasında koordinasyon oluşturulması. Kaymakamların ayrıca doğum, ölüm ve evlilik gibi olayların kayıt edilmesi ile ilgili idari görevleri bulunmaktadır. Kaymakam köy şûrası seçimlerini organize eder. Bu meclisler köylerde gerçekleşen doğum, ölüm ve evlilik kayıtlarının yapılmasından sorumludurlar. İlçe bürosu ise bu bilgilerin toplanması ve birleştirilmesinden sorumludur. Kaymakam ilçenin kalkınma planının izlenmesi ve uygulanmasına yardımcı olacaktır.

Kaymakamın resmi yetkilerinin yanı sıra önemli ölçüde informel yetkisi ve gücü bulunmaktadır. Kaymakam kendi kişisel ilişkilerini kullanarak ilçenin işlerine nüfuz eder. Kaymakam ilçe düzeyinde işleri yürütmek için kendi nüfuzunu kullanarak memurları belirleyebilir. Bu bazen kamu işlerinde yolsuzluğa sebep olmaktadır. Afganistan, örf ve geleneklerin hala çok önemli olduğu bir ülkedir. Kaymakamın önemli görevlerinden birisi ilçedeki çatışmaların çözülmesidir. Bundan dolayı, kaymakamlar yerel yaşlılar ile toplantı yapar ve ilçedeki sorun ve çatışmaları çözmeye çalışır.

Türkiye'de ise kaymakam, merkezi idarenin taşradaki ilçe düzeyindeki temslcisi ve yöneticisidir. Kaymakam il valisinin denetimi altındadır. Afganistan'da ve Türkiye'de valiler hem idari hem de siyasi kişilerdir. Kaymakamlar kanun, tüzük, yönetmelik ve valinin komutlarını uygulamalıdırlar. Kaymakamlar her konuda vali ile iletişimi kurmalıdır (Eryılmaz, 2013:156). Afganistan'da kaymakamlar merkezi bakanlıklar ile iletişim kuramazlar. Ancak Türkiye'de kaymakamlar valilikler üzerinden bakanlıklar ile iletişim kurabilirler.

\subsection{2. İlçe Meclisleri}

İlçe meclisleri, ilçelerde halkı temsil eden üyelerden oluşan meclistir. Anayasaya göre, ilçe meclislerinin üye sayısı her ilçenin nüfusuna göre değişir. Bu meclisler bulundukları ilçeye göre beş ile on beş arasında üyeye sahiptir ve her üç yılda bir seçim yapılır. İlçe meclislerine aday olacak kişiler ilçenin sakinlerinden olmalıdır. Bugüne kadar iki sebepten dolayı ilçe meclisi seçimleri yapılamamıştır. Bu sebeplerden ilki ilçelerin sınırlarının henüz kesinleşmemiş olmasıdır ki; bu da bir ilçenin nüfusunun belirlenmesi ve ilçe meclisindeki koltuk sayısının hesaplanmasını imkânsız kılmaktadır. İkinci sebebi ise seçmen kayıtlarının ilçe düzeyinde yapılmamış olmasıdır. Bu da beraberinde nüfusun hesaplanması sorununu getirmektedir. Bu nedenle seçimler il düzeyinde yapilmaktadır (Vahed Tahkik ve Arzyabi Afganistan, 2012:84).

İlçe meclisinin görev ve sorumlulukları şunlardır (Afganistan Belediye Kanunu, md.4):

- İlçe meclisi, ilçe düzeyinde geleneksel meclisler ve CERGE aracığıyla sivil toplum kuruluşları ve vatandaşların ilçe yönetimine katılmasını ve bu katılımın geliştirilmesini sağlar.

- İlçe meclisi vatandaşlarla ve sivil toplum kuruluşları ile düzenli bir şekilde danışma toplantıları yapar.

- İlçe meclisinde geliştirme planları onaylanır ve ilçe düzeyinde geliştirme planlarının uygulanmasının sağlaması ve gözetimi yapılır.

- İlçe meclisinin ana görevi yerel kurum ve kuruluşların vatandaşlara karşı hesap verebilirliğini sağlamaktır. Kaymakam güvenliğin sağlanması, insan haklarının geliştirilmesi, istikrarlı yönetimin gerçekleştirilmesi ve kanun egemenliği hedefinin gerçekleştirilmesi konularında ilçe meclisine bilgi verir.

- İlçe meclisi her ay kaymakamın çalışma raporunu alıp inceler. Bu inceleme sonucunda gerekirse vali ve cumhurbaşkanlığına şikâyette bulunabilir. İlçe meclisi ilçe raporlarını yayınlamalıdır.

- İlçe meclisinin önemli görevlerinden birisi de bakanlıkların temsilcilerinin hizmet sunumunu ne kadar kaliteli yaptığının izlenmesidir.

- İlçe meclisi vatandaşların şikâyet mekanizmalarının denetlenmesinden sorumludur. Bu şikâyetler hizmet sunumunun kalitesi ve vatandaşlar ile ilgili konular olabilir. Kaymakam ve ilçedeki kurumlar vatandaşların şikâyetlerine karşı sorumludur.

- İlçe meclisi ilçedeki çatışma ve sorunları tarafların rızasıyla çözer.

- İlçe meclisi zorla evlendirme, bad dadan zan gibi şeriat hukukuna aykırı geleneklerin ortadan kaldırılması için ilgili makamlarla işbirliği yapar. 


\subsection{3. İlçe Kalkınma Derneği}

Kırsal Rehabilitasyon ve Kalkınma Bakanlığı'nın ulusal programlarından birisi ilçe kalkınma derneklerinin oluşturulmasıdır. İlçe kalkınma derneklerinin ana görevleri şunlardır: ilçenin önceliklerini tanımlamak, ilçeye kalkınma planlaması konusunda yardım etmek, planlamanın yönetimi, uygulanması ve izlenmesini gerçekleştirmek ve bu konuda kaymakama tavsiyelerde bulunmaktır. İlçe kalkınma derneği, görev sahasındaki vatandaşların önceliklerine ve ihtiyaçlarına göre ilçenin kalkınma planlarını düzenler. Ayrıca yerel düzeyde kalkınma programları için kurumlar arasında koordinasyonu sağlar (Afganistan Yerel Yönetim Politikası, 2010:87).

\subsection{Belediyeler}

Afganistan'da belediyeler idari ve yasal kurumlardır. Bir belediye birkaç semet (semt) oluşturmaktadır. Bir alan ise birkaç mahale birleşmesinden meydana gelmektedir. Afganistan'da belediye kavramı ilk kez 1923 y1lında Amanullah döneminde çıkarılan belediye kanunu ile idari düzen içerisinde yer almıştır. Ancak Türk siyasi tarihine baktığımızda belediye kavramına çok eski tarihlerden itibaren rastlanmaktadır. Türkiye'de ilk kez 1854 y1lında İstanbul Şehremaneti (Belediyesi) kurulmuştur. 1871 yılından itibaren de ülke genelinde başka belediyeler kurulmuştur. "Belediyeler; yerel demokrasi, mali yönetim, insan kaynakları, hizmet sunulan nüfus ve etkin hizmet sunumu açısından Türkiye'deki diğer yerel yönetim birimleri arasında öne çlkmaktadır" (Ateş ve Köseoğlu, 2011:71).

Afganistan'da Belediye kanunu 2018 yılında onaylanmıştır. Yeni belediye kanuna göre belediye oluşturma kriterleri şunlardır (Belediye Kanunu, md.4):

- Belirli bir coğrafi alana (en az 5 kilometralik) sahip olmak,

- En az 10.000 nüfusa sahip olmak,

- Gerekli konfor getirmesi ve temel kamu hizmetleri karşılaması için finansal yeterliliğe sahip olmaktır.

ABD'nin Afganistan'ı işgal etmesinden sonra Bağımsız Yerel yönetim Müdürlüğünün bir kurul aracıllı̆̆yla, belediyelerin faaliyetlerini incelemeye başladığı görülmektedir. İl veya ilçe belediyelerinin çoğu doğrudan vali ve il idari meclisine rapor vermektedir. Belediyeler kamu mallarını yönetmesi, kamu adına sözleşmeler yapması ve kamusal ihtiyaçların karşılanması için oluşturulmuştur. Belediyelere karşı dava açılabildiği gibi belediyeler de diğer kurumlar veya kişilere karşı dava açabilmektedir. Afganistan'da Kamu İşleri Bakanlığı'na kayıtlı 181 belediye bulunmaktadır. Ancak, savaş nedeniyle bunlardan sadece 153'ü aktif olarak çalışmaktadır. Aktif olarak çalışan belediyelerin ise 33 tanesi il belediyesi olup geri kalan 120 tanesi de ilçe belediyesidir. Belediyeler yerel halkın ihtiyaçlarını, merkezi kurum politikaları aracılığıyla gelir kaynakları üzerinden karşılamaktadırlar. Diğer bir ifadeyle, vatandaşların ihtiyaçlarını yerel gelir kaynakları üzerinden karşılamaktadırlar. Bu sebeple gelir kaynaklarının yetersizlikleri, kamu hizmetlerinin yetersizliklerini de beraberinde getirmektedir.

Belediyeler aşağıdaki hizmetlerin sağlanmasından sorumludurlar:

- Gıda temini ve dağıtımı

- Sosyal-ekonomik temel hizmetler

- Hastalıkların yayılmasını önleme

- Kültürel, sportif faaliyetler ve okuma yazma öğretilmesi

- Cenaze hizmetleri, hukuki destek ve benzeri sosyal hizmetler

- Su, kanalizasyon sistemi, yollar, spor tesisleri, kültürel ve tarihi merkezler, sivil merkezler, kamu parkları, toplu taşıma tesisleri, konut ve ticaret alanlarının altyapılarının yapılması ve bakımıdır.

Tarım hizmetleri, iletişim ve benzeri altyapı hizmetleri ise merkezi hükümetin sorumluluğundadır ve doğrudan onlar tarafından planlanır ve sunulur. Belediyeler ise, bu planları uygulamak için ilgili kurumlarla işbirliği yaparlar. Belediyeler bunun dışında özerk bütçeye sahiptirler çünkü kendilerinin de gelir elde etme gücü vardır. Bir dereceye kadar da bu gelirleri özgürce kullanabilmektedirler. Ancak mali planlama ve harcama konusunda sınırsız bir bağımsızlık söz konusu değildir. Belediye bütçesi eğer yeterli değilse, merkezi hükümet tarafından kaynak tahsisi yapılabilir. Belediye bütçesi, belediye başkanı tarafindan düzenlenir ve belediye idari şûrası tarafından onaylanır. Maliye Bakanlığ 
(Afganistan Yerel Yönetim Politikası, 2010:231). Bakanlar Kurulu bütçeyi onayladığı zaman belediyeler bu bütçeyi kullanabilir. Bakanlar Kurulu bütçeyi uygun görmez ve geri gönderirse belediyeler tarafindan bütçe tekrar düzenlenerek yeniden Bakanlar Kuruluna gönderilir. Ancak genel itibariyle her belediyenin kendi yeterli bütçesi bulunduğundan bütçe Bakanlar Kurulu tarafından onaylanmakta ve böyle bir olumsuzluk yaşanmamaktadır. Ancak burada belediyelerin yeterli bütçeye sahip olması mevzuatta öngörülen kamu hizmetlerinin tamamını gerçekleştirebilecek yeterli düzeyde finansal kaynağının bulunması olarak algılanmamalıdır. Yapılmak istenen öncelikli hizmetlere daha yalın bir ifade ile yapılacak giderler ve ayrılan kaynağın denkleştirilmesi olarak dikkate alınmalıdır. Çünkü mevzuatta öngörülen birçok kamu hizmetinin sunumu için belediyelerin yeterli mali kaynakları bulunmamaktadır.

Ülkede sağlık, eğitim, yol, elektrik gibi temel hizmetler belediyelerin sorumluluğundadır. Ancak, yine de bu hizmetler doğrudan doğruya Bakanlar Kurulu tarafından düzenlenmektedir. Çünkü, belediyelerin bütçesi bu uygulamalardaki eksiklikleri gidermede yeterli değildir. Bakanlar Kurulu tarafindan gerçekleştirilen hizmetlerin uygulanmasındaki denetiminden ise belediyeler sorumludur. Bu nedenle belediyeler bu hizmetlerde baş sorumlu olmamakla birlikte etkilidirler ve Bakanlar Kurulu ile işbirliği içerisindedirler. Ancak Kabil Belediyesi diğer belediyelerden farklı bir konuma sahiptir. Kabil belediyesi merkezi hükümetin bir parçası gibidir ve doğrudan merkezi hükümete karşı sorumludur. Hükümet Kabil Belediyesi için özel düzenlemeler yapabilir. Kabil Belediyesi'nin ana sorumluluğu Kabil halkının refahı için gerekli hizmetleri sağlamaktır.

\subsubsection{Belediye Başkanı}

Belediye başkanı, belediye meclis üyeleri arasından üç yıllığına seçilir (Kanun İntehabatı Şarvali, 2003:md.7). Belediyelerden sorumlu başkanlık (Deputy Ministry of Municipalities) ile İnsan Kaynakları Genel Müdürlüğü tarafından ortak bir şekilde oluşturulan birleşik komite belediye başkanının seçilmesinden sorumlu tutulmuştur. Bu komite önerileri alıp değerlendirir. Değerlendirmesini daha sonra Bağımsız Yerel Yönetim Müdürlüğüne gönderir. Belediye başkanının esas itibariyle seçimle işbaşına gelmesi düşünülmüştür. Belediye başkanı seçimlerinde oyların yüzde ellisinden fazlasını alan aday kazanan olarak ilan edilmesi, eğer adaylardan hiçbiri oyların yüzde ellisinden fazlasını kazanamazsa, iki hafta sonra en çok oyu kazanan iki aday arasında ikinci tur seçimlerin yapılması planlanmıştır. Ancak bugüne kadar belediye başkanlığı için herhangi bir seçim yapılmamıştır. Belediye kanununa göre, belediye başkanı halk tarafından seçim yolu ile göreve getirilmektedir. Ancak, uygulamada seçimler yapılmamış ve başkanlar merkezden atama yapılarak göreve getirilmiştir. Bu da beraberinde göreve gelen bazı belediye başkanlarının yeterli donanıma sahip olmaması ve bundan dolayı görevini düzgün bir şekilde yerine getirememesi gibi sorunlara neden olmuştur.

\subsubsection{Belediye Başkanının Görevleri}

Belediye başkanının görevi şunlardır:

- Plan ve programları uygulayarak yerel halka hizmet sunmak,

- Belediye yönetimi ile ilgili bütün kanunları uygulamak,

- Belediyenin yetki altındaki konularda düzenlemeler yapmak,

- Vergi ve belediyenin gelirlerinin toplamasını takip etmek,

- Ruhsat ve izinleri düzenlemek, ertelemek ve iptal etmek,

- İnşat için izin düzenlemek ve imar kontrolü yapmak,

- Belediyenin arazisini korumak,

- Belediye personelini yönetmek ve denetlemek,

- Belediye şûrasının yardımı ile ekonomik-geliştirme planlarını yönetmek,

- Belediye meclisinin alacağı kararlarda (regulation) teklifte bulunmak,

- Vali ve diğer merkezi kurumlara belediyenin yönetimi, belediyenin gelişimi, belediyenin siyasi, ekonomik ve sosyal faaliyetleri ile ilgili rapor vermek (Afganistan Yerel Yönetim Politikası, 2010:248). 


\subsubsection{Belediye Şûrası}

Anayasada belediye şûrasının özgür, gizli ve doğrudan bir şekilde yapılacak seçimle oluşacağı vurgulanmıştır. Bununla birlikte Anayasa ve seçim kanununda belediye şûrasının çalışma alanı ve görevleri net değildir (Vahed Tahkik ve Arzyabi Afganistan, 2012:85). Belediye şûrasının seçim bölgesi şehirdir. En fazla oyu alan adaylar belediye şûrasının üyesi olarak seçilecektir. Belediye şûrası üyeleri üç sene için seçilir. Ancak seçimler yapılamadığı için belediye şûrası henüz resmi bir şekilde oluşturulmamıştır.

Belediye şûrasının görevleri şunlardır; belediye tüzüklerini (statüde) çıkarmak, kanunların uygulanmasıyla ilgili kararlar vermek, belediye bütçesini onaylamak, belediyeye ait olan vergi ve ücretlerin fiyatlarını belirlemek, belediyenin hizmet ettiği halkı temsil etmek, belediyeyi teftiş etmek ve değerlendirmek, belediyenin hesap verebilirliğini sağlamak, bütçe uygulamalarını denetlemek, kalkınma amaç ve hedeflerini belirlemek için işbirliği yapmak, belediye hizmetlerinde etkinliğin sağlanması için kalkınma önceliklerini tanımlamak ve gerekli tedbirleri uygulamak, belediye planlarının uygulamasını teftiş etmek ve değerlendirmek, belediyenin sorumluluk alanındaki halk ile belediye başkanı ile belediyenin diğer yetkili organları arasında istişare toplantıları düzenlemek, şeffaflık ve daha iyi bir hesap verebilirlik için halka görüşlerini bildirme fursatı sağlamak, belediyenin her türlü, vergi, harç, ücret ve belediye mülklerinin kiralarını onaylamak, belediyenin bütçe harcamalarını izlemek ve değerlendirmektir. Bunların yanı sıra belediye personeli görevi ile ilgili kuralları uygulamazsa veya görevini yerine getirmezse, belediye şûrası tarafindan belediye başkanına ilgili personel hakkında ceza önerisinde bulunulabilir (Afganistan Yerel Yönetim Politikas1, 2010:251-252).

\subsubsection{Belediye İdari Meclisi}

Her belediye yapısında bir belediye idari meclisi vardır. Belediye idari meclisi, belediye başkanı, belediye başkan yardımcısı ve belediye şube müdürlerden oluşturmaktadır. Belediye idari meclisi daha ziyade bütçe ve finans konularında yetkilidir. Belediye idari meclisinin yetkileri şu şekildedir (xxxxxxkanunu, md.???):

- Belediye müdürlükleri faaliyetlerinin koordine edilmesi,

- Belediyenin ekonomik, sosyal ve yıllık yatırım planlarının düzenlenmesi ve belediye şûrasına sunulmadan önce bu konularda genel bir anlaşmaya varılması,

- Belediyenin yıllık bütçesinin hazırlanması ile onay ve takibi için belediye şûrasına sunulması,

- Belediye şûrasına karar tasarısında bulunulması,

- Belediye şûrasına karar vermesi için gerekli konuların önerilmesi,

- Belediyenin öncelediği olan plan ve programların incelenmesi,

- İstihdam, atama, terfi, cezalandırma ve eğitim gibi belediye yönetimi ile ilgili eylemlerin onaylanması,

- Belediyenin yönetimi ve eylemlerine rehberlik eden yönetmelik ve kararların onaylanmasıdır.

Gelişmiş örgütü bulunan belediyeler farklı görev alanlarına sahip birimlerden oluşmaktadır. Bu birimler ihtiyaç duydukları bütçe ile donatılmıştır. Bu birimlerin görevleri imar kontrolü, çevre temizliği, ölçülerin kontrol edilmesi ve halk şikâyetlerinin alınması şeklindedir.

\subsection{Köy Yönetimi}

Afganistan'da yerel örgütlenmeler genel olarak yerel düzeydeki, eğitim, ulaşım, sağlı ve kamu hizmetleri sunulmasından sorumludurlar (Muqimi, 2015:19). Bir yerel örgütlenme türü olarak ele alacağımız köy yönetimleri de yerel düzeyde kamu hizmetleri ifa etmekle görevlidir. Coğrafi açıdan en yerel ve küçük düzeyde faaliyet gösteren bu birimlerin kanunlarda belirtilen hukuki yapısı ile uygulamadaki fiili yapısı arasında bazı farklılıklar bulunmaktadır. Köy yönetiminin temeli olan organlar ve yönetimde söz sahibi olan kişiler bu birimin genel çerçevesini oluşturmaktadır.

Köy yönetiminin temel organları: muhtar, köy şûrası ve köy kalkınma meclisidir. Köyde ayrıca resmi görevi olmayan, ancak yönetimde etkili olan kişi ve geleneksel kurumlar da bulunmaktadır. Efendi ya da ağa olarak adlandırılan ve çok toprağı olan bu kişiler, bazen resmi kurumlardan daha etkili ve önemli rollere sahip olabilmektedirler. Bu kişilerin temel olarak devlet ve halk arasında iletişim kurmaktan sorumlu oldukları 
söylenebilir. Çergeler (bir tür yerel meclis) ile ilgili işler, doğum kayıtlarının tutulması ve evlilik işlerinin düzenlenmesi bu kişilerin ilgilendikleri temel konulardır. Bu kişiler, köydeki halk tarafından seçilir ya da bu işi babadan oğula miras olarak devralırlar. Bu kişilerin yanı sıra ihtiyar, marşal ve dini liderler yerel düzeyde güç sahibidirler. Özellikle dini lider pozisyonunda bulunan ulemanın büyük bir gücü bulunmaktadır. ABD işgalinden sonra bile bu güç varlığını devam ettirmiştir (Murtazashvili ve Murtazashvili, 2015:162). Türkiye'de ise köylerde muhtarlar 5 yıl için köy halkı tarafından seçilir. Babadan oğula geçmesi ya da merkez tarafından atanması söz konusu değildir.

Türkiye'de muhtarlar ceza hukuku açısından kamu görevlisi sayılırlar. Ancak devlet memuru değildirler. Bununla birlikte devletten aylık/maaş alırlar. Muhtarlar köy düzeyinde işlerini yerine getirmek için köy derneği ve köy ihtiyar meclisi ile çalışmaktadırlar (Eryılmaz, 2013:220-221). Türkiye'de merkezi idarenin taşra birimleri ile ilgili mevcut kanun yaklaşık 70 yıllıktır. İhtiyaca göre de sık sık maddelerinde güncelleme yapılmaktadır. Yerel yönetimler ile ilgili de temel kanunlar 2004-2006 yıllarında yenilenmiştir. Ancak köy kanunu 1924 tarihlidir. Türkiye şartlarına göre ivedilikle yenilenmesi gerekmektedir. Ancak bu haliyle köy yönetimi konusundaki etkinliği, hesap sorulabilirliği, denetimi ve görev/yetki belirginliği Afganistan'a göre daha iyi düzeyde olduğu düşünülmektedir.

\subsubsection{Muhtar}

Köy yönetimi bağlamında muhtarlık kabile düzeninden kalma bir unsurdur. Eski dönemlerde, muhtar kendisini hükümetin tam yetkiye sahip temsilcisi olarak kabul ediyordu ve yerel hükümdarları tatmin etmek için yerel halkı eziyorlardı. Anayasa açısından muhtar, Afganistan'ın idari yapısı içerisinde sayılmaktadır. Ancak muhtarlığın kamu tüzel kişiliği bulunmamaktadır. Yasaya göre her köyde halk tarafından yetkin bir kişi, muhtar olarak seçilmektedir. Muhtarın temel görevi köylüler ile ilçe yönetimi arasındaki iletişimi sağlamak ve yerel örgütlerin emirlerini köy halkına iletmektedir (Afganistan Yerel Yönetim Politikas1, 2010:198).

\subsubsection{Köy Şûrası}

Köy Şûrası, Afganistan yerel yönetiminin en alt düzeyini oluşturur. Ülkede nüfusun birçoğunun köylerde yaşıyor olması köy şûrasının yönetimdeki önemini ve etkisini artırmaktadır. Anayasaya göre köy şûrası seçimlerinin özgür, gizli, doğrudan bir şekilde yapılması gerekmektedir. Köy şûraları üç yıllık bir dönem için seçilir. Ancak köy şûrasının çalışma alanı ve görevleri anayasa ve seçim kanununda net bir şekilde ortaya konulmamıştır (Vahed Tahkik ve Arzyabi Afganistan, 2012:85). Köy şûrası, köyün gelişim planlarını düzenlerler. Bunun yanı sıra bakanlıkların yerel temsilcileri, kaymakamlar, ilçe meclisi ve diğer yönetim kurumları ile işbirliği yaparlar. Köy şûrası, köyün gelişme planlarını gerçekleştirmek için ilgili planı hazırlayarak kaymakama sunmakla görevlidir.

Köy Şûrasının genel olarak; köyün gelişme planlarını yapmak ve uygulamak, kamu hizmetinde performans yönetimini sağlamak ve değerlendirmek, sivil toplum ve medya ile iletişim kurmak, barış, güvenlik, düzen ve istikrarın korumasına yardımcı olmak, para yönetimi ve kullanma yetkisine sahip olmak, güvenlik, bölge ayrılması ve inşaat yapımı ile ilgili yönetmelikleri düzenlemek, sosyal güvenliği sağlamak, köydeki insanlar arasındaki çatışmaları çözmek, doğal kaynakları yönetmek, arazilerin kaydını (tescili) yapmak ve köyün coğrafi sınırlarını belirlemek, köyün nüfus kayıtlarını yapmak, üst düzeydeki yönetim kurumlar ile işbirliği yapmak, köydeki tüm resmi ve gayri resmi kurumların faaliyetlerini izlemek ve değerlendirmek gibi görev ve sorumlulukları vardır. Ayrıca Köy şûrası yası dışı gelenekler ve örflerin ortadan kaldırılması konusunda da çaba göstermektedir (Afganistan Yerel Yönetim Politikas1, 2010:201).

\subsubsection{Köy Kalkınma Meclisi}

Afganistan'da geçici hükümetin kurulmasından sonra yeniden yapılanma çalışmaları başlamıştır. Kırsal Rehabilitasyon ve Kalkınma Bakanlığı, kırsal kalkınma amacıyla köy kalkınma meclislerini kurmuştur. Köy kalkınma meclisi, köyün kalkınma planlarının düzenlenmesinden sorumludur. Köy kalkınma meclisi, kalkınma projelerinin uygulanması için verilen parayı Ulusal Koalisyon Programı (National Solidarity Programme) aracılığıyla alır. Nitekim Kırsal Rehabilitasyon ve Kalkınma Bakanlığı, köylerin yeniden yapılanma sürecini hızlandırmak için Ulusal Koalisyon Programını başlatmıştır. Ulusal Koalisyon Programı köylerin kalkınması için başlatılmış bir girişimdir. Ancak bu program il ve ilçe düzeyinde de uygulanmaktadır. Ulusal Koalisyon Programı vatandaşları projelerin uygulanmasına katılmaya teşvik eder. Ulusal Koalisyon Programı Afganistan'daki kalkınma programının başarılı bir parçasıdır. Çünkü hemen hemen bütün illerde ve 364 ilçeden 359'unda faaliyettedir. Bu program aracılığıyla yaklaşık 22 bin köyde kalkınma meclisi oluşturulmuştur. Bu program köy düzeyinde projelerin belirlenmesi ve uygulanmasından sorumludur (Markezi İtalat ve Resane Hay Hükümet, Mardum ve Barname Hambastegi Mili, 2010:1). 


\section{SONUÇ}

Afganistan kamu yönetiminin daha etkin ve verimli bir yapıya kavuşması amacıyla tarihsel süreçte birçok yenilik ve iyileştirme çabaları yapılmıştır. Özellikle uzun yıllar devam eden savaşlar sonrasında ülke yönetiminde değişikliklere gidilmiştir. Ancak, yapılmak istenen değişimlerin genellikle kanun düzeyinde kaldığ ve birçok konuda uygulamaya geçilmediği görülmektedir. Afganistan'da alt düzeydeki yerel kurumlar kurulamamıştır. İl şûrasının altında yer alan diğer şûralar da kurulamamıştır. İlçe şûrası, köy şûrası ve belediye seçimleri gibi konulara hükümet odaklanamamıştır. Bu alanlarda seçimler yapılamamış ve ilgili yönetimler meclisler- teşkil edilememiştir. Uzun yıllardır devam eden savaşların ve savaş sonrası ülkede etkili olan ABD etkisinin bu olumsuz durumda önemli payı vardır. Ülkede bir türlü sağlamlaştırılamayan demokratik yapı nedeniyle Afganistan, geri kalmış bir ülke profiline sahiptir.

Afganistan yönetim sistemi incelendiğinde, hukuki olarak tesis edilmiş ancak fiiliyatta hayata geçirilememiş idari birimler ve aktörler ile hukuken bir varlığa sahip olmamakla birlikte geleneksel varlığını devam ettiren illegal aktörler ve oluşumlar bir arada bulunmaktadır. Olması gereken ile mevcut olanın tezat bir şekilde bir arada bulunması, sistemin meşruluğu konusunda tartışmaların ortaya çıkmasına neden olmaktadır. Bu olumsuz tablonun, hukukun ve kamu gücünün halk tarafından içselleştirilmesine olumsuz etki ettiği düşünülmektedir.

Demokratik ülkelerde kurumların uygulamaları yasaya uygun olur. Ancak geri kalmış ülkelerde uygulamalar kabilesel, kişisel, siyasi ve parasal etkilere göre belirlenir. Şüphesiz ki kabile taassubu ve ilgili çatışmalar da Afganistan toplumunu etkileyen bir başka sorun olmuştur. Afganistan kamu yönetiminde yaşanan bu temel sorunlar, beraberinde yolsuzluğun birçok kamu kurum ve kuruluşunda neredeyse açık bir şekilde yapılmasına neden olmaktadır. Topluluk düzeyinde işlerini doğru bir şekilde yapmaya çalışan çok az insan bulunmaktadır. İdealist sayılabilecek bu insanlar da maalesef bu büyük kalabalığın içinde azınlık konumunda kalmaktadır.

Afganistan'da tarihsel süreç içerisinde çok kültürlü ve değişken toplumsal yapıların bir arada bulunması, yönetsel anlamda da bazı sorunları beraberinde getirmiştir. Özellikle etnik gruplar arasındaki mücadeleler ve ülkenin sürekli olarak dış tehdit ve işgaller altında bulunması, homojen ve uyumlu bir siyasal sistemin kurulmasına engel olmuştur. Rusların asimilasyonu ve aşırı baskıcı politikaları nedeniyle bağımsız ve evrensel düşünceye hakim aydın bir sınıfın yetişmesi ciddi anlamda engellenmiştir. Ülke üst, orta ve alt yönetimindeki kadrolar genellikle Rus eğitiminden geçmiş ve onların güdümünde olan kişilerden oluşmuştur. Özellikle baskın toplulukların idarede etkinleşme çabaları liyakat sisteminin oluşmasına olumsuz etki etmiştir. Yakın zamanda ABD'nin Afganistan'a müdahalesinden sonra Rus baskısı yerini ABD işgaline bırakmıştır. Şüphesiz bu durum da Afganistan'da ideal bir siyasal ve yönetsel sistemin kurulmasına katkı sağlamamaktadır. Bu sebeple ülkedeki kamu kurumları modern bir yapılanmadan, donanımdan ve optimal görev-yetki dağılımdan oldukça uzaktır. Modern bir devlet yapılanmasını tesis edecek modern kadroların yetişmesi yerine var olan yönetsel kadrolar da devlet yönetiminden uzaklaşmaktadır. Büyük bir çoğunluğu daha iyi şartlar sunan özel sektöre geçiş yapmıştır. $\mathrm{Bu}$ durum Afganistan bürokrasisinin gelişmesine olumsuz bir etki oluşturmaktadır.

Sonuç itibariyle Afganistan kamu yönetimi kendi içerisinde birçok problemi olan ve yerel örgütlenme boyutuyla da büyük ölçüde merkeziyetçi bir yapıya sahiptir. Yani idari sistem, merkezi yönetime göre tanımlanmıştır. Merkezi yönetim il ve ilçe düzeyindeki yönetim süreçlerini belirlemektedir. İlgili atamalar daha ziyade merkezden ve Cumhurbaşkanı tarafından yapılmaktadır. Bu durumda yerel düzeydeki şûraların rolü genel olarak danışma rolünde kalmaktadır. Bu oluşumların merkezi idareye karşı etkinliği ve yaptırım gücü oldukça düşük düzeydedir.

Bütün bu karşılaştığımız problemlerin incelenmesi sonucunda; ülkedeki yerel yönetimlerin güçlendirilmesi, kamu kurum ve kuruluşlarındaki görev dağılımının nitelikli ve görev bilinci taşıyan kişilerce yapılması, özellikle de bürokrasinin ülkenin çıkarlarını düşünen ve gelişimini destekleyen kişilerce yapılması gerekmektedir. $\mathrm{Bu}$ da beraberinde uygulamaların kanun maddesi olmaktan çıkıp ülke yönetiminde etkin hale gelmesini sağlayacak ve özelden genele tüm kurumlardaki aksaklıkları giderecektir. Sağlam bir bürokrasinin oluşturulduğu ülkede ise şüphesiz kabile reisleri veya benzeri güç sahibi kimseler değil; halkın çıkarlarını ve menfaatini düşünen kişiler kurumlarda yetki sahibi olacaktır. Bu da ancak her demokrasi ülkesinde olduğu gibi seçimle ve halkın özgür iradesinin söz sahibi olmasıyla mümkün olacaktır. Ancak tüm bunların olağan bir şekilde ve yakın bir zamanda gerçekleşeceğini düşünmek gerçeklikten uzak bir yaklaşım olacaktır.

Afganistan'da halkın ihtiyaçlarına cevap verecek, modern ve uyumlu bir idari sistemin oluşması öncelikle bağımsız bir devletin varlığı ile söz konusu olacaktır. Ülkenin tam bağımsızlığı ise en başta kabile, etnik ve 
diğer sosyal grupların savaşmak yerine birarada bulunmayı tercih etmesi ile mümkündür. Bu düşüncenin inşaası ve hayata geçirilmesi de evrensel değerlere hakim, çok yönlü, önyargılarından arınmış, bilinçli ve ileri görüşlü kadroların ortaya çıkması ve sorumluluk alarak yönetimlerde yer almasıyla gerçekleşebilecektir. Bu da toplumsal yapıda insana değer vermek ve dünya ile bütünleşme neticesinde söz konusu olabilecektir. Ancak daha önce Ruslar tarafından yapıldığı gibi an itibariyle de ABD tarafından bu değerlerin ve gelişmelerin ortaya çıkması sert bir şekilde engellenmektedir. Ülke toplumsal kutuplaşma ve kavgalarla oyalanırken, yönetsel aktörler uluslararası aktörlerin güdümünde ve onların isteklerine göre görevlerini yerine getirebilmektedirler.

\section{KAYNAKÇA}

AFGANISTAN BAĞIMSIZ YEREL YÖNETIM MÜDÜRLÜĞÜ (2010), "Afganistan Yerel Yönetim Politikası", E-Rapor, https://idlg.gov.af/laws/ (Erişim Tarihi: 06.11.2017).

AFGANISTAN BAĞIMSIZ YEREL YÖNETIM MÜDÜRLÜĞÜ (t.y.), "İdare Mahali", E-Rapor, http://idlg.gov.af/fa/page/idlg/history (Erişim Tarihi: 06.10.2017).

AHMADY, Mohhamad Amin (2015), "Barresi Çand ve Çun Kanun Asasi Afganistan", Eslahat, Tagir ve Tusee dar Afganistan (Ed. Camşid Yama), Talaş Yayınları, Kabil.

ANDİşMEND, Mohhamad Akrem ( 2014), Dolat Milet Sazi Dar Afganistan, Sait Yayıncılık, Kabil.

ARVIN, Ayub (2015), "Şûrahaye Mahali Çera Gudret Nadarand", BBC, 12.02.2015, http://www.bbc.com/persian/afghanistan/2015/02/150210_k02_afghan_local_councils_power (Erişim Tarihi: 03.04.2019).

ATEŞ, Hamza ve KÖSEOĞLU, Özer (2011), Belediyelerde Kurumsal Performans Yönetimi, İlke Yayınc1lik, İstanbul.

BEGZAD, Ruhullah (2014), "11 Eylül Sonrası Afganistan'da Demokratikleşme ve Taliban Örgütü", Yüksek Lisans Tezi, Gazi Üniversitesi Sosyal Bilimler Enstitüsü, Ankara.

BEKMURADİ, Najibullah (2014), "2001 Sonrasi Siyasi Partilerin Afganistan'da Demokratik Düzene Katkisı", Yüksek Lisans Tezi, Gazi Üniversitesi Sosyal Bilimler Enstitüsü, Ankara.

BLOOD, Peter R. (1998), "Afghanistan a Country Study", Library of Congress, Federal Research Division, Washington D.C.

BÜYÜKBAŞ, Murat (2006), "Amerika Birleşik Devletleri'nin Afganistan'a Müdahalesi ve Afganistan'a Oluşturulan Yeni Yönetim Yapısı", Yüksek Lisans Tezi, Süleyman Demirel Üniversitesi Sosyal Bilimler Enstitüsü, Isparta.

ERYILMAZ, Bilal ( 2013), Kamu Yönetimi, Umuttepe Yayınları, İstanbul, 6. Bask1.

ESTANUKZAY, Nasir (2013), Sistem İdari ve Teşkilati Afganistan-e Muasır, Sait Yayıncılık, Kabil.

GUBAR, Mir Gulam Mohhamad (2011), Afganistan Dar Masire Tarih, Erfan Yayıncılık, Tihran, 2.Cilt.

KOÇAK, Yüksel (2013), Türkiyede Yerel Yönetimler, Siyasal Kitabevi, Ankara.

MARKEZI İTALAT VE RESANE HAY HÜKÜMET (2010), Mardum ve Barname Hambastegi Mili, http://www.gmic.gov.af/dari/features/62-nsp (Erişim Tarihi: 10.11.2017).

MOHAMADY, Zeynep (2014), "Caygahe Şûrahayl Velayeti dar Afganistan", BBC, 04.03.2014, http://www.bbc.com/persian/afghanistan/2014/03/140224_k04_afg2014_provincial_council_info (Erişim Tarihi: 13.07.2016).

MUQIMİ, Muhammad (2015), İdare Umur Hükümet hay Mahali, Qum, 8. Basım.

MURTAZASHVILI, Ilia ve MURTAZASHVILI, Jennifer (2015), "Anarchy, Self-Governance, And Legal Titling", Public Choice, S.162, ss.287-305.

RAHMANI, Edris (2015), "Se Ulaviyet Umde Dulet Vahdat Meli", Eslahat, Tagir ve Tusee dar Afganistan (Ed. Camşid Yama), Talaş Yayınları, Kabil.

SARAY, Mehmet (1989), "Afganistan", İslam Ansiklopedisi, Türkiye Diyanet Vakfı Yayınları, İstanbul, Cilt 1. 
SİRET, Hüseyin (2014), Hesab Dehi ve Şefafiyet dar İdarat Mahali Tagviyet Mişavad, Rozname 8 Sobh., (28.10.2014).

T. C. DIŞIŞ̧LERİ BAKANLIĞI (2019), "Afganistan İslam Cumhuriyeti Ülke Künyesi", Dışişleri Bakanlığı Kurumsal Web Sayfası, http://www.mfa.gov.tr/afganistan-kunyesi.tr.mfa (Erişim Tarihi: 08.04.2019).

T. C. KABİL BÜYÜKELÇİLIĞİ TİCARET MÜŞAVİRLİĞİ (2017), Afganistan Ülke Raporu, Kabil Büyükelçiliği Ticaret Müşavirliği Yayını, (Yer Yok), https://www.kutso.org.tr/wpcontent/uploads/2017/06/Afganistan.pdf (Erişim Tarihi: 08.04.2019).

TAMAKİ, Abdul Ali Mohamady (2011), Hukuk İdari Afganistan, Erfan Yayınc1lık, Tihran.

VAHED TAHKIK VE ARZYABI AFGANISTAN (2012), Az Alıf ta Ya Kitabi Rahnama Barayı Komak be Afganistan, www.areu.org.af (Erişim Tarihi: 13.07.2016).

WIKIPEDIA SÖZLÜK (2019), "Afganistan Coğrafyası", Wikipedia Elektronik Sözlük, https://tr.wikipedia.org/wiki/Kategori:Afganistan_coğrafyası (Erişim Tarihi: 19.04.2019).

37 sayılı Afhanistan Teşkilat Asası Kanunu (05.10.1965 tarih ve 1965 Resmi Ceride).

323 sayılı Afganistan Belediye Kanunu (05.06.2018 tarih ve 10 sayılı Resmi Ceride).

753 sayılı Afganistan Mahali Kanunu (10.10.1991 tarih ve 13 say1lı Resmi Ceride).

994 sayılı ve 2005 tarihli Afganistan Yerel Polis Kanunu, (11.059.2008 tarih ve 1047 sayıl1 Resmi Ceride).

1226 sayılı ve 2016 tarihli İntihabat Kanunu, (25.09.2016).

5302 sayı1ı İl Özel İdaresi Kanunu (04.03.2005 tarih ve 25745 sayılı Resmi Gazete) 